\section{Learning Events in the Life of a Community of Mathematics Educators}

\author{
Orit Zaslavsky, Haifa (Israel)
}

\begin{abstract}
The paper examines some characteristics of learning events of a community of mathematics educators. Participation in the community entailed gaining familiarity with agreed upon conventions, goals, and forms of communication. The case discussed herein is an attempt to convey the complexities underlying learning in such a community through (re)negotiation of practices and goals. The notion of reflective discourse is borrowed to describe a group discussion involving collective reflection that constituted an occasion for meaningful learning.
\end{abstract}

Kurzreferat: Lernereignisse in einer Gemeinschaft von Mathematiklehrer(innen). Im Beitrag werden einige Charakteristika von Lernereignissen in einer Gemeinschaft von Mathematiklehrer(inne)n untersucht. Die Arbeit in der Gemeinschaft unterstützt, mit vereinbarten Konventionen, Zielen und Kommunikationsformen vertraut zu werden. Die im Beitrag diskutierte Fallstudie versucht die Komplexität aufzuzeigen, die einem Lernen durch Aushandlungen von Praxis und Zielen in solch einer Gemeinschaft zugrundeliegt. Mit Hilfe des Begriffs des reflektiven Diskurses soll eine Gruppendiskussion mit kollektiver Reflexion beschrieben werden, die Möglichkeiten für bedeutsames Lernen schafft.

ZDM-Classification: B50, C50, C69, C70, D20, D30

\section{Conceptual framework}

The present work addresses processes associated with the evolution of shared goals, and conceptions of necessary conditions for and indicators of worthwhile change within a community of mathematics educators, aiming at improving the mathematics teaching practice. This community included junior and high school mathematics teachers as well as a diverse group of experienced and highly reputable mathematics educators who served as teacher-educators within this community.

One of the main characteristics of a community, compared to a collection of people, is the existence of shared common goals and collaborative efforts directed towards the accomplishment of these goals (Roth 1998; Lave \& Wegner 1991). Collaborative efforts are meaningful only if goals are part of the agreed upon conventions by the members of the community. In the context of a teachers' professional development program the collaborative construction of mutual goals is considered an evolutionary process in the learning community. The collaborative construction of goals entails learning in a social context. In this context, learning is seen as a gradual process of peripheral participation in a community of practice (Brown, Collins \& Duguid 1989). Accordingly, situated learning relates social practices with collaborative construction of knowledge, rituals, practices, language and other conventions (Brown et al. 1989; Lave \& Wenger 1991; Hennessy 1990). The negotiation process by which practices are developed and conventions established is therefore viewed here as a learning process aimed at gradual construction of a community. It follows that teacher development is then basically a learning process within the context of a professional community (Bell \& Gilbert 1994). Gradual participation in a community entails gaining familiarity with agreed upon conventions, goals, and forms of communication. Yet, certain events in the life of a community may lead to the negotiation of modified conventions. The case discussed herein is an attempt to convey the complexities underlying learning in such a community through (re)negotiation of practices and goals.

An increasing number of researchers, sharing a social view of learning, recognize the power of working together and contemplate that teachers' participation in a learning community is extremely important for their professional growth (e.g. Stein \& Brown 1997; Cobb \& McClain 2001; Krainer 2001, 2003; Gellert 2003; Lachance \& Confrey 2003; Zaslavsky, Chapman \& Leikin 2003). The suggested forms of collaboration vary with respect to their settings and goals, however, all of them attempt to foster joint reflection. Moreover, several researchers posit that an essential component of a community of practice is associated with the notion of reflective activity, which is considered an effective factor contributing to the growth of teachers' knowledge about their practice (Dewey 1933; Schön 1983; Steinbring 1998; Krainer 2001). Nonetheless, facilitating meaningful reflection, both individually and jointly, for members of a community who have not previously engaged in deliberate reflection as part of their practice, is a non-trivial task. In their discussion of mathematics teacher-educators' roles, Zaslavsky and Leikin (2004) point to the dual nature of teacher-educators' practice - on the one hand they are expected to facilitate teachers' reflection, while they are also expected to constantly reflect on their own experiences.

Borrowing from Cobb, Boufi, McClain \& Whitenack (1997), the notions of reflective discourse and collective reflection correspond, with slight modifications, to the kind of reflective discussions in which the members of the community of mathematics educators engaged. The work presented in this paper provides glimpses into means to stimulate meaningful reflective discourse among diverse members of a community and its power in terms of dealing with problematic issues related to collective conceptions of goals and proposed changes in practice.

Goals of teacher development may be specific and rather well defined, such as improving teachers' knowledge in a specific domain or gaining familiarity with new curricular materials, while other goals may aim at deeper 'second order' changes (Tirosh \& Graeber 2003), the nature of which is harder to transmit in words. Goals can be pre-determined or negotiated (Krainer 2003). The initial goals of a program are usually set by one or more designers and reflect their image of teachers' profession. Once the program is implemented, teachers construct its goals based on their own world view of needs, experience, professional and personal issues. The extent to which goals and efforts diverge is an indication 
of the state of the community. For example, in reference to a community of practice established by Erickson, Mayer-Smith and Rodriguez (1994), the authors suggest that the community provided both the opportunities and the means for dealing with participants' dilemmas that challenged the existing goals and conventions.

\section{The professional development program ${ }^{1}$}

The work described in this paper was conducted within the framework of a five-year reform-oriented in-service professional development program ("Tomorrow 98" in the Upper Galilee) for junior and senior high school mathematics teachers (Zaslavsky \& Leikin 2004), with newcomers - both teachers and teacher-educators - gradually joining during the first three years.

The goals of the designers of the program concur with what Cooney and Krainer (1996), Ball (1997), and Tirosh and Graeber (2003) consider essential components for effective teacher education programs. More specifically, the program's goals included the following:

- Enhancing teachers' knowledge (both mathematical and pedagogical), beliefs (about mathematics and about teaching) and practices, in ways that support a reformoriented mindset and a constructivist perspective to teaching. In particular, the program aimed at encouraging teachers to move from teacher-centered to a more student-centered and cooperative learning modes (in the spirit of NCTM, 2000), incorporating technological tools.

- Facilitating teachers' (as well as teacher-educators') ability to reflect on their learning and teaching experiences as well as on their personal and social development.

- Fostering teachers' and teacher-educators' socialization and developing a supportive professional community to which they belong.

It should be noted that stating the above list of goals at the beginning of the program would be meaningless. Most of these goals needed to be communicated through the program's activities and the participants' personal experiences. As one of the teacher-educators said towards the end of the second year of the program, as she reflected on her work: "It took us two years to begin to understand what was meant by the goals that were presented to us at the beginning. Only now I'm starting to feel that we are talking the same language".

In total, about 120 teachers participated in the program. Participation was done voluntarily, although all teachers in the region were encouraged to join, and incentives were offered to the participating teachers, in terms of compensation for the time they devoted to the program. In addition, each participating teacher received a personal portable computer. This was done in order to use the educational technological advances as a driving force for changing the teaching practice (Yerushalmy, Chazan \& Gordon 1990; Laborde 2001; Tirosh \& Graeber 2003).

1 Zaslavsky \& Leikin's (2004) study was based on the same program and share some of the data collected.
The teachers were grouped according to the grade levels they taught (junior/senior high grades) and the year in which they enrolled in the program. Altogether, there were six groups of teachers each consisting of about 20 teachers. During the first three years of the program, two new groups of teachers joined the program each year one junior high and the other senior high school level.

Within each group, the participating teachers varied along several dimensions, e.g., the textbooks that they used, the particular mathematical topics that they were teaching, the level of their students, the size of their classroom, and the availability of additional resources. The underlying assumption was that the program should support all the teachers, regardless of their specific professional background and circumstances. The teachers who participated in the full program took part for four consecutive years in weekly professional development meetings for six hours per week, throughout each school year. The meetings consisted of a wide range of activities led mainly by the project team. Some of the teachers gradually became more involved in the program and towards their third year assumed responsibility for many of these activities. Due to ongoing reflective discourse and negotiations of meaning among the various members of the community, as the program progressed the location of the activities shifted from a central regional location into the schools in the region, organized mainly as study groups, similar in a way to the study groups described by Arbaugh (2003). That is, these groups consisted of "educators who come together on a regular basis to support each other as they work collaboratively to both develop professionally and to change their practice" (Arbaugh 2003, p. 141).

The project team, that is the group that served as mathematics teacher-educators, consisted mainly of experienced and highly reputable secondary mathematics teachers, some of which continued to teach mathematics in their schools. Although there were altogether over 20 team members, only 14 were involved in the program from its early stages until its completion. The team members varied with respect to their expertise and experience, one of the characteristics that Roth (1998) considers essential to a community. None of them had any prior formal training to become a teacher-educator. Some did not have any previous experience in mentoring or teaching other teachers. In the initial stages of the program, the tasks of the staff members were mostly directed towards designing and carrying out in-service workshops through which the program goals were conveyed. $\mathrm{Nu}$ merous additional directions and activities were initiated by various members of the community - teachers and teacher-educators - as the program developed. For example, the participating teachers initiated mutual visits to each other's lessons as well as time to share their classroom experiences and deal with problems of implementation; teacher-educators began visiting schools and providing support for teachers who were reluctant in implementing innovative teaching practices; an annual mathematics fair was planned and carried out, in which teachers and students gave presentations and displayed a variety of individual and group project work. In short, although the content and structure of the program was pre-determined 
to a certain extent, inherent to it was attentiveness the participants' (changing) needs and flexibility to address these needs as they arose.

\section{A meaningful learning event in the life of the com- munity}

As mentioned earlier, the initially stated goals of the program were the kind that words could not fully convey. How does one explain what is meant by a 'constructive perspective to teaching' without reflecting on appropriate experiences? Moreover, how does one 'instruct' beginning teacher-educators how to conduct a workshop in a 'reform-oriented spirit'? Thus, the teachers and teachereducators' conceptions of the goals and ways to accomplish them evolved through their practice and participation in the community, in an apprenticeship like manner (Rogoff 1990). Deliberate actions were taken to facilitate this development (as detailed in Zaslavsky \& Leikin 2004).

I turn to a description of a 'meaningful learning event' in the life of the project that was effective in shaping a common language and deepening the understanding of mutual goals and pitfalls on the road directed to their accomplishment. I draw on it to discuss some of the complexities of implementing classroom changes. This event led to individual reflection as well as reflective discourse and created a sense of conflict and disequilibrium for teachers and teacher-educators, a state that according to Schwan Smith (2001) is one of the key features of highquality professional development experiences. It all began with unenthusiastic reactions of three $10^{\text {th }}$ grade students to the change in their teacher's practice.

\subsection{Students' reactions to the changing practice of their teacher as a stimulus for reflection}

In the third year of the program, we followed closely Amy ${ }^{2}$, an experienced teacher with a sound mathematical and pedagogical background who participated in the program from its outset. Amy was one of the teachers who seemed to have modified her practice in ways that were consistent with the goals of the program. That is, her lessons were rather student-centered, allowing students to work cooperatively in small groups. She incorporated the use of technology in her calculus classes, focusing on students' explorations of functions in an open computer software environment. She would give students open ended assignments, encouraging them to raise conjectures and verify them. She refused to assume the role of the authority for 'the right answer', and encouraged her students to provide logical support for their claims.

Amy's views of the goals of the program evolved through her participation in its various activities. In particular, she derived her views mainly from her encounters as a reflective learner in numerous workshops, on a variety of topics (mathematical and pedagogical), in which she was exposed to different teaching styles. Generally, Amy was very satisfied with the program, and claimed that she had many opportunities to experience powerful

\footnotetext{
2 All the names in the paper are pseudonyms.
}

learning situations. It should be noted that Amy taught in a school that provided full support for the teachers to implement reform oriented teaching.

A number of Amy's lessons, in which she implemented her interpretation of the recommended changes in classroom practice, were videotaped. Some of the videotaping was done by a professional documentary film producer Adam with an unusual sound mathematical knowledge. For a period of about two years, Adam spent a lot of time observing the various activities of the project.

In one of Amy's videotaped lessons in a top level $10^{\text {th }}$ grade mathematics class, in which her students seemed rather involved in the computer explorations of periodic functions, a few of Amy's students were asked what they thought of her 'new way of teaching'. Three of them expressed considerable dissatisfaction. Drora, one of the best students in the class, said that

"Now Amy explains less and we have to think more for ourselves. This is more complicated. I prefer to be fed with a spoon. Computer explorations irritate me ... Just because I chose to learn in this extended level of the math curriculum, doesn't mean that it truly interests me".

Ilan, a less successful student in this class, contested that

"I understood better before. Now I often don't know what I'm actually doing or expected to do, and don't always know if I'm doing it right or not".

David, a third student, elaborated on this point and said:

“Now I don't feel as good as before. The teacher doesn't explain as much. We work a lot on our own. I learned better before. It was easier. Yet, it is more interesting this way".

These reactions of the students served as a stimulus for an interview that Adam conducted with Amy and for a meeting with the group of teacher-educators. In the interview with Amy, who was in the middle of her third year of enrollment in the program, she was asked to describe her new practice and relate to what her students said. A month later, a staff meeting of the program's teacher-educators was scheduled. In this meeting, Adam showed some video clips with the students' reactions. He began by reflecting on the way he saw the program:

Adam: There is something in the essence of what you are trying to do that works with the teachers but may not be appropriate for the students. They may not be mature enough for this. I didn't see there [in Amy's classroom] the enthusiasm that I see here [at the workshops]. They [the students] didn't really engage in a genuine mathematical investigation. It's complicated. There were 15 students that worked seriously. They were really into it. But I didn't see that they were enthusiastic.

\subsection{Elements of reflective discourse in the context of the community of mathematics educators}

The video clips stimulated much reflection of the participants, which was extremely meaningful to them. They reflected on a number of dimensions: on their views of goals and practices; on their own mathematical disposition; on their personal experiences as learners, as teachers, and as teacher-educators; and on reflection itself. The latter was particularly interesting, since most staff members found it very difficult to stimulate genuine 
and sincere reflection with the teachers. The reflective discourse in which they engaged led them to realize the difference between the deep and meaningful reflection they encountered and the kind of reflection they had been trying to foster with teachers.

Figure 1 presents the main objects of reflection that were addressed. Naturally, the context of the reflective interview and discourse that are discussed in this paper lends itself to reflection on actions rather than reflection in action. The elements of reflection are interconnected, and often inseparable. While the reflective discourse of the group led to all the elements of reflection that appear in Figure 1, in Amy's interview, which basically focused on her personal classroom practice, she related to most but not all of these elements.

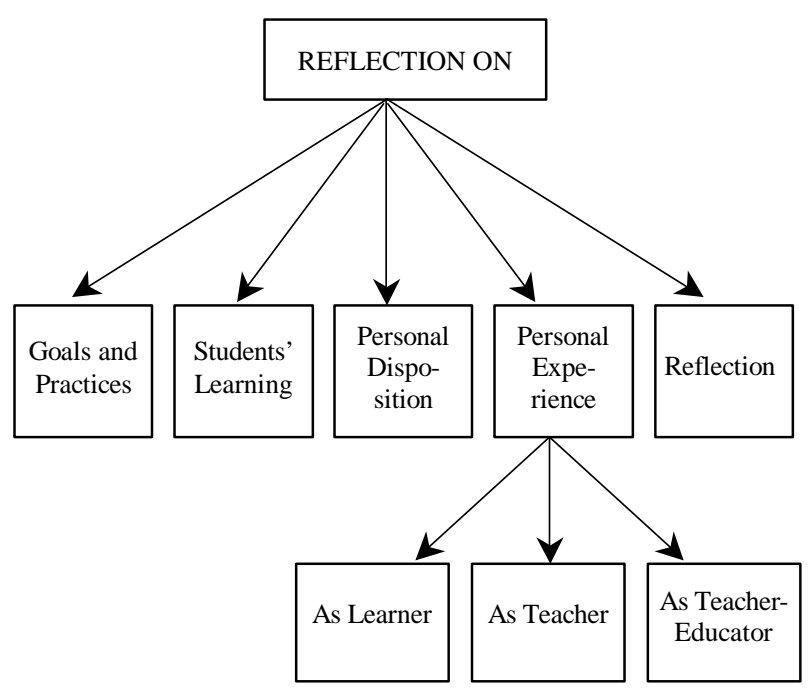

Fig. 1: Elements of Mathematics Educators' Collective Reflection

The following excerpts, from Amy's interview and from the staff meeting, illustrate the kind of reflection that took place. They are organized according to the elements in Figure 1.

\section{Reflection on goals, values, and practices:}

The video clips provoked participants to (re)consider the main goals that they attributed to the program. Interestingly, of the web of goals to which the program was directed, they focused on two: enhancing students' mathematical thinking and their drive towards mathematics. For the first time, these two goals seemed conflicting.

Amy: I strongly believe in the program's outlook. The innovation in the recommended teaching practice is not just the use of the computer. What we need to do is teach our students to think, after years in which they were 'fed with a spoon'.

The computer is just a tool. The aim is mathematics and a different way of thinking. This tool enables us to observe numerous examples instantly. It's a concrete tool that promotes thinking. They [the students] need to translate what they see, what it means. With respect to functions - they can notice symmetry, extreme points, tangents etc. This way prepares them better for independent thinking.
Helen: I'm happy to hear that they have to think. However, it's strange that David said that now he understands less but it's more interesting. If this is the full picture, if we don't bring them to like mathematics better than before - we will be missing the opportunity to really make a difference. I feel very badly about this.

Orna: I believe that the teacher has the responsibility to do everything possible so that each student will have something that excites him in mathematics, and that is relevant to his world.

\section{Reflection on students' learning and disposition:}

Several concerns regarding students' difficulties to adjust to the changes in their teacher's practice were raised. Amy seemed very confident in her new way of teaching. However, the confrontation with students' difficulties led to the realization that students must be true partners in this process and should be convinced of the merits of this new approach to teaching. Until this point, a lot of attention was drawn to the demanding task of supporting change in teachers' practice. This conflicting situation drew attention to another critical partner for any change the student. A strong tension arose between the desire attend to students' immediate needs and the conviction that in the long run they will benefit from this new practice. As reflected in the excerpts - this event enhanced the participants' sensitivity to students as learners of mathematics (Jaworski 1994). This element of reflection was the most dominant in this event.

Amy: Naturally, there are a few students in my class that don't like this approach. They keep asking me questions such as: 'What should I write in my notebook? How should I summarize what we are doing?' In implementing such change it's not enough to change the teachers, we also need to convince the students. They need to be convinced. You can't make changes in one day, particularly if for the students this change is in only one subject out of about 15 subjects that they study.

Some students claim that they understood better before. I question this assertion. Before, they may have known better in a very technical way, so they felt as if they understood. Ilan, who said he understood better before, originally was not supposed to be in this [5 point level] class. He really belongs to the 4 point level. If I taught him technically he may have succeeded better in the short term. I believe that if one has a deep understanding s/he will also remember more.

Now they face much fuzziness. There aren't always unifying rules, and not always yes or no answers. There are often more exceptions than commonalities. Everything is open. There are questions with no definite answers. In the last lesson, they couldn't generalize and say that the sum of any two periodic functions is always a periodic function and couldn't say that any such sum is never a periodic function. It depends and needs constant examination.

I don't want to summarize our findings for them. I want them to be involved and suggest how to summarize what they got.

Even Drora said she felt ok in the lesson. At least it was tolerable for her. Part of it is the need to invest efforts. This she doesn't like. She was used to getting 100 easily with no effort. Math is not the direction in which she would like to major. 
Lily: It's not at all surprising. They are accustomed to learn differently. The change causes uncertainty and reduces their confidence. At the end, we need to give them the answers ... In every method some students don't want to invest any efforts.

Sara: I want to point to a positive aspect of what they said. This is an indication that the goal that we are aiming at has been partially accomplished - they have to think. She [Drora] complained because she has to get used to it. This is a change that they are encountering.

Jane: Drora said that mathematics is not her main concern. She wants to be told what she needs, without having to break her head. Her motivation to study in the top level math is mere calculation [of future prospects for higher education]. Mathematics doesn't interest her.

Helen: Thank you for showing us the video. It is thought provoking. I may be wrong, but my feeling is that the problem rests on the change in the teaching methods. Amy, unlike what they were accustomed to, posed questions and didn't give answers and didn't explain. Their difficulties are not necessarily because of the computer but more because of the teaching mode. We must think more about this and be aware of it.

Lily: Maybe exploration tasks don't suit everyone?

Shula: Things aren't a dichotomous. It's not as if before we dictated everything and now there is only vagueness and confusion. Our students and us all are undergoing change. We teach them to think mathematically. I believe it will take time, but we must continue persistently.

Orna: The positive thing here is that a change is happening. Many changes involve pain. Maybe in time this will become their habit, and when we offer them [the students] the answer they will ask us to give them time to think on their own. We need to know when to tell them to think for themselves and when to give them the answer. Sometimes, at the beginning of a process of change we tend to take things to an extreme. I'm sure every child can enjoy thinking.

\section{Reflection on personal mathematical disposition:}

The participating mathematics educators shared deep appreciation and enthusiasm of mathematics. Some drew on their love for mathematics in connection to students' lack of interest.

Amy: It's impossible to transmit our love for mathematics to everyone. Even if the lesson turns from a nightmare to a stimulating experience, it still doesn't mean that everyone will like mathematics.

The light in my eyes when I do mathematics is not necessarily what students' eyes will express. Mathematics teachers are a special population of people who generally like mathematics.

Lily: We love mathematics, but this doesn't represent the entire population.

We can see the beauty in mathematics. We like it. Not all the students do.

\section{Reflection on personal experiences as a learner:}

In the course of the musings surrounding the conflict that arose, some mathematics educators reflected on their experiences as learners. While Amy drew on her experience as a teacher in the program's workshops, Ruth - one of the teacher-educator - reflected on her general preferences as learner.

Amy: Several students said they don't know what exactly they are doing. It's a problem to summarize. To us too, in the program's workshops, we often engage in explorations where many things are not completely clear, and sometimes only at the very end the 'coin drops' and we get the full picture.

Ruth: People are different. I, for instance, can't learn in groups with other people. It is personal. We have to incorporate the various innovative approaches with caution, and vary what we do in the class.

\section{Reflection on personal experiences as a teacher:}

Most of the teacher-educators in the program continued to teach in their schools. They became very sympathetic with Amy's position and tried to put themselves in her shoes and draw comparisons between their experiences and hers.

Lina: In my school, $7^{\text {th }}$ grade students talk about learning with computers quite differently. They can't wait for the next lesson. It's a matter of age. A lot of their habits and work patterns broke. The earlier we introduce this change the better. Senior high school grade students don't manage to deal with fuzziness. It's also very difficult for us too. How will we correct tests with open ended questions, where each student gives a different answer?

Shula: I am very disappointed. It bothers me. I wonder if this reflects the whole picture. In my class last year, they were happy with the change.

Jason: The reality that we just saw contradicts our feelings. In my school all the students are very enthusiastic. There is a big difference between an assignment that I gave for working with a computer off the top of my head and one which I carefully designed.

Judith: Some worksheets have the final answers at the end and some don't. We want them [the students] to think and evaluate the reasonability of their answer - is it right because the book says so, or are there other reasons why it's right. The video evoked in me hard feelings. Partly because I am in a similar situation as Amy is. When I teach in my class I feel a lot of joy, and now I'm beginning to think that my students may be unhappy. I often hear my students say 'it was really very hard now', but I sense in their voice happiness and satisfaction that they overcame the difficulty. Some are happy and some get frustrated. Up to now I felt that it is good, but now I'm not sure anymore. Maybe if my students were interviewed they would say the same. I must interview them next week.

\section{Reflection on personal experiences as a teacher-educa- tor:}

A number of teacher-educators reflected on their experiences as facilitators of teachers' learning in the workshops.

Helen: It happened to me too that one of the teachers who participated in a workshop of mine told me that it bothered her that I don't summarize it.

Ruth: Why not summarize [at the workshop]? 
Helen: Because they [the teachers] should think. But for some this is confusing, and they may need a summary. We should rethink this. I don't think it" just a matter of the grade level (that is, $10^{\text {th }}$ grade).

\section{Reflection on reflection:}

As mentioned earlier, most staff members were not satisfied with their attempts to stimulate meaningful reflection with the teachers. The collective reflection in which they engaged evoked their thoughts on the issue of reflection.

Lina: This turns on a red light - after every 5-10 lessons let's ask our students what they think and feel about it. Reflection should go hand in hand with any aspect of implementing change.

Judith: Just before this meeting, I was going to share with you my frustration about facilitating teachers' reflection. I'm not satisfied with my ability to do it. Nothing could have stirred our own reflection as this did. What we did here is actually reflection on reflection.

Helen: I became defensive, and this inhibited my ability to reflect.

Jane: The usual reflection is agitating. It's hard to facilitate a sincere and profound discussion. This was an example of stimulating and relevant reflection.

To give a perspective on the students' reactions that stirred this discussion, at the end of the staff meeting Adam felt he had to conclude with what he had sensed:

Adam: Out of the 40 hours that I've been filming here I could only find 6 minutes with a potential to provoke you ... So please take this in proportion.

\section{Concluding remarks}

The event in the life of the community of mathematics educators presented above is an example of an authentic and meaningful learning opportunity for all participating members. It involved (re)negotiation of practices and goals, through collective reflection. This event became part of the common language that developed and served as a reference example to remind us of the complexities of the terrain. It entailed a lot of the issues that Cooney and Shealy (1997) address in their discussion of changes in teachers' practices. In particular, it shifted the attention to students as critical participants, in accordance with what Tirosh and Graeber (2003) maintain: "Other, obvious but often overlooked participants in the change process are the students. ... Teachers need to be aware of students' perspectives, prepare students for the change, and support them as they experience new expectations and new classroom values" (p. 661).

In terms of goals and practices, one issue that came up repeatedly was the view that the recommended change suggests that the teacher does not summarize any part of the lesson. This was never stated as a goal. It was some teachers' and teacher-educators' interpretation of moving from teacher-centered to student-centered teaching. By reflecting on this interpretation of the programs' goals, it was made explicit, and became open for negotiation. Clearly, "no summaries" was not the intended goal of the program initiators.
Finally, similar to Cobb et al's (1997) accounts of reflective discourse in the mathematics classroom, also in the above discussion "reflection was supported and enabled by participation in the discourse" (Cobb et al 1997, p. 264). Each individual contributed to "the development of the discourse that sustained collective reflection". In our case too, the participation in the discourse constituted an occasion for learning within the community of mathematics educators.

\section{References}

Arbaugh, F. (2003): Study groups as a form of professional development for secondary mathematics teachers. - In: Journal of Mathematics Teacher Education, 6(2).

Ball, D. L. (1997): Developing mathematics reform: What don't we know about teacher learning - but would make good working hypotheses. - In: S. N. Friel; G. W. Bright (Eds.), Reflecting on our work: NSF teacher enhancement in K-6 mathematics. Lanham, MD: University Press of America, Inc., p. 77-111.

Bell, B; Gilbert, J. (1994): Teacher Development as Professional, Personal, and Social Development. - In: Teaching and Teacher Education 10 (5), p. 483-497.

Brown, J. S.; Collins, A.; Duguid, P. (1989): Situated cognition and the culture of learning. - In: Educational Researcher 18(1), p. 32-42.

Cobb, P.; Boufi, A.; McClain, K.; Whitenack, J. (1997): An approach for supporting teachers' learning in social context. In: Journal for Research in Mathematics Education 28(3), p. 258-277.

Cobb, P.; McClain, K. (2001): An approach for supporting teachers' learning in social context. - In: F.-L. Lin; T. J. Cooney (Eds.), Making sense of mathematics teacher education. Dordrecht, The Netherlands: Kluwer Academic Publishers, p. 207-231.

Cooney, T. J.; Krainer, K. (1996): Inservice mathematics teacher education: The importance of listening. - In: A. J. Bishop; K. Clements; C. Keitel; J. Kilpatrick; C. Laborde (Eds.), International handbook of mathematics education. Dordrecht, The Netherlands: Kluwer Academic Publishers, p. 1155-1185.

Cooney, T. J.; Shealy, B. E. (1997): On understanding the structure of teachers' beliefs and their relationship to change. - In: E. Fennema; B. Scott-Nelson (Eds.), Mathematics teachers in transition. Mahwah, NJ: Lawrence Erlbaum Ass., p. 87-109.

Dewey, J. (1933): How we think: A restatement of the relation of reflective thinking to the educative process. - Boston: D.C. Heath and Co.

Erickson, G.; Mayer-Smith, J.; Rodriguez, A. (1994): Perspectives to teach science insights and dilemmas from a collaborative practicum project. - In: International Journal of Science Education 16(5), p. 585-597.

Gellert, U. (2003): Researching teacher communities and networks. - In: Zentralblatt für Didaktik der Mathematik 35(5), p. 224-232.

Hennessy, S. (1993): Situated cognition and cognitive apprenticeship: Implications for classroom learning. - In: Studies in Science Education 22, p. 1-41.

Jaworski, B. (1994): Investigating mathematics teaching: A constructivist enquiry. - London: Falmer Press.

Krainer, K. (2001): Teachers' growth is more than the growth of individual teachers: The case of Gisela. - In: F.-L. Lin; T. J. Cooney (Eds.), Making sense of mathematics teacher education. Dordrecht, The Netherlands: Kluwer Academic Publishers, p. 271-293.

Krainer, K. (2003): Teams, communities and networks (editorial). - In: Journal of Mathematics Teacher Education 6(2), p. 93-105. 
Laborde, C. (2001): The use of new technologies as a vehicle for restructuring teachers' mathematics. - In: F.-L. Lin; T. J. Cooney (Eds.), Making sense of mathematics teacher education. Dordrecht, The Netherlands: Kluwer Academic Publishers, p. 87-109.

Lachance, A.; Confrey, J. (2003) : Interconnecting content and community: A qualitative study of secondary mathematics teachers. - In: Journal of Mathematics Teacher Education 6(2), p. 107-137.

Lave, J.; Wenger, E. (1991): Situated learning: Legitimate peripheral participation. - Cambridge: Cambridge University Press.

National Council of Teachers of Mathematics (NCTM) (2000): Principles and standards for school mathematics. - Reston, VA: Author.

Rogoff, B. (1990): Apprenticeship in thinking: Cognitive development in social context. - New York: Oxford University Press.

Roth, W.-M. (1998): Designing communities. - Boston: Kluwer Academic Publication.

Schön, D. A. (1983): The reflective practitioner: How professionals think in action. - New York: Basic Books.

Schwan Smith, M. (2001): Practice-based professional development for teachers of mathematics. - Reston, VA: National Council of Teachers of Mathematics.

Stein, M.; Brown, C. (1997): Teacher Learning in a Social Context: Integrating Collaborative and Institutional Processes with the Study of Teacher Change. - In: E. Fennema; B. Nelson (Eds.), Mathematics teachers in transition. Mahwah, NJ: Lawrence Erlbaum Associates, p. 155-191.

Steinbring, H. (1998): Elements of epistemological knowledge for mathematics teachers. - In: Journal of Mathematics Teacher Education 1(2), p. 157-189.

Tirosh, D.; Graeber. A. O. (2003): Challenging and changing mathematics classroom practices. - In: A. J. Bishop; M. A. Clements; C. Keitel; J. Kilpatrick; F. K. S. Leung (Eds.), Second International Handbook of Mathematics Education. Dordrecht, the Netherlands: Kluwer Academic Publishers, p. 643-687.

Yerushalmy, M.; Chazan, D.; Gordon, M. (1990): Mathematical problem posing: Implications for facilitating student inquiry in classrooms. - In: Instructional Science 19, p. 219-245.

Zaslavsky, O.; Chapman, O.; Leikin, R. (2003): Professional development in mathematics education: Trends and tasks. In: A. J. Bishop; M. A. Clements; C. Keitel; J. Kilpatrick; F. K. S. Leung (Eds.), Second International Handbook of Mathematics Education. Dordrecht, the Netherlands: Kluwer Academic Publishers, p. 875-915.

Zaslavsky, O.; Leikin, R. (2004): Professional development of mathematics teacher educators: Growth through practice. In: Journal of Mathematics Teacher Education 7(1), p. 5-32.

\section{Author}

Zaslavsky, Orit, Department of Education in Technology and Science, Technion - Israel Institute of Technology, Haifa 32000, Israel

E-mail: orit@tx.technion.ac.il 